\title{
敷島公園を事例とした収益施設（カフェ）の利用意向とイメージ分析に関する研究
}

\section{A study on intention to use profit facilities measurement of park users' behavior in Shikishima park}

\author{
塚田 伸也* 森田 哲夫**
}

\author{
Shinya TSUKADA Tetsuo MORITA
}

\begin{abstract}
In this study, we conducted a study on a city park where the Designated Manager System was introduced and where a profit facility (cafe) was developed by Park-PFI. The target park is Shikishima Park in Maebashi City, Gunma Prefecture, a large-scale park. The purpose is to grasp the intention of using the cafe and the evaluation of the user about the park management. According to a web questionnaire survey, $63 \%$ of the people intend to use the cafe, and $36 \%$ of the people who use the park more frequently by opening a cafe. From the free opinions, we were able to grasp the tendency to have a good image of use such as an increase in usage opportunities and an increase in the attractiveness of the park and a bad image of use such as congestion of parking lots and an increase in garbage. The more people who use the park, the higher the intention to use the cafe. From the above, we obtained valuable information to verify the effects of the designated manager system and Park-PFI.
\end{abstract}

Keywords: Shikisima park, intention to use profit facilities, evaluation structure キーワード：敷島公園，収益施設，評価構造

\section{1. はじめに}

\section{(1) 背景}

我が国では，自治体の厳しい財政状況の中，施設の老朽化の進 行を踏まえ，都市公園のストックを適切に維持管理していく環境 が厳しさを増している。都市公園については，以前から設置管理 許可等を活用し，官民連携による管理が行われてきたが，1999 年に「民間資金等の活用による公共施設等の整備等の促進に関す る法律」(PFI 法)の制定, 2003 年に地方自治法の改正により「指 定管理者制度」が導入されるなど官民連携手法が多様化している。

指定管理者制度は，現在全国の都市公園で導入されており，そ の要因の 1 つには，事業者間の価格競争による維持管理費の削減 等の効果が考えられる。指定管理者制度の場合，行政は必要とさ れるサービスの水準（要求水準）のみを民間事業者に提示し，具 体的な手法や実施手順について民間事業者の提案に委ねるという 方法 (いわゆる「性能発注」) が可能である。民間の発想を生かし た経営効率化の手法の導入や利用者に対する接客やサービス提供 のノウハウの発揮等により，民間事業者の能力を最大限に引き出 し，公共サービスの質の向上が期待できることも，指定管理者制 度が普及した要因と考えられる 1)。

また，2017 年には，都市公園法が改正され，飲食店，売店等の 公園利用者の利便の向上に資する公園施設の設置と，当該施設か ら生ずる収益を活用してその周辺の園路，広場等の整備，改修等 を一体的に行う者を, 公募により選定する「公募設置管理制度 (以 下, Park-PFI)」が設けられた。Park-PFI は, 飲食店や売店など の公園利用者にとって，利便の向上に資する公募対象公園施設を 設置するとともに，当該施設から生じる収益を活用することによ って，その周辺の園路や広場等の公園利用者が一般に利用できる 特定公園施設の整備・改修等を一体的に行う者を公募によって選 定する制度である 2)。

以上のように，増大している都市公園を適切に維持管理するた め，指定管理者制度や Park-PFI 等の官民連携手法による制度が
活用されており，今後も官民連携による都市公園の管理運営は工 夫により様々な展開が期待される。

一方で，都市公園における官民連携は，あくまで手段であるた め，民間活力を最大限活用し公園管理の維持管理コストを縮减で きても，本制度の主目的である都市における賑わい空間の創造や 利用者サービスといった，都市公園の魅力向上を損なわないよう な管理運営を行う必要がある 3)。このため，本研究は官民連携に よる都市公園の魅力づくりの視点に着目し取り組むものである。

\section{(2) 既往研究と本研究の位置づけ}

本研究に関連して，都市公園の魅力づくりと官民連携に関する 研究をレビューする。はじめに都市公園の魅力づくりに関する研 究としては, 都市公園の利用を評価する研究が数多く行われてい る。塚田ら 4) ${ }^{4}$, 前橋市の総合公園, 運動公園など大規模公園を 対象に，利用者からみた公園の評価構造を明らかにしている。

官民連携による都市公園の活用としては，指定管理者制度の導 入以降，塚田ら 5)が都市公園における指定管理者の選考基準の現 状と選考時の評価構造について分析，前田 6)が，公園利用者を対 象とした満足度調査により, 制度導入前後の満足度の比較，制度 導入公園における比較を行い，制度導入の影響を考察している。 また, 竹田ら 7)は, 全国の都道府県営都市公園の年度評価の実態 を調査し，評価項目と指定管理者の業種，都市公園の種別との関 連性を明らかにしている。上原ら ${ }^{8)}$ は，大規模公園に導入された 指定管理者制度に関し，業務評価と指定管理募集の上限額の設定 方法の関係性を中心とする制度運用の実態を明らかにしている。 以上のように，指定管理者制度については，公園利用者からの評 価や制度運用に関する研究がみられる。

都市公園における PFI については, 印部ら 9)が都市公園の整備 事業にPFI 手法を導入した事例について, 導入のタイミング, エ リア設定，事業手法について比較考察している。Park-PFI 導入 以降は，宋ら 10)が設置管理許可制度を用いたパークマネジメント における設置管理事業者の関与実態を明らかにし，山崎ら ${ }^{11) か ゙ ~}$

\footnotetext{
*前橋市都市計画部 *前橋工科大学
} 


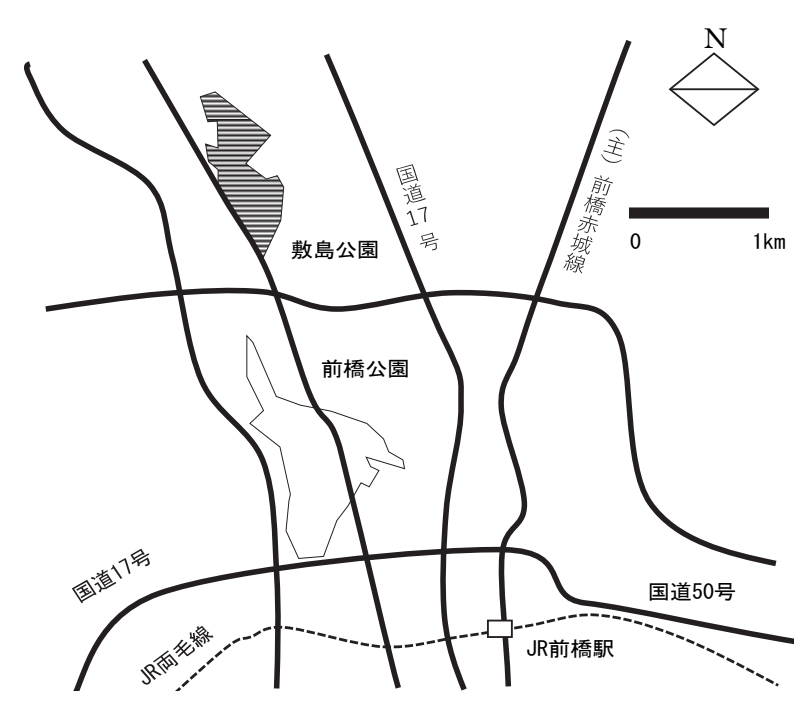

図-1＼cjkstart敷島公園の位置図

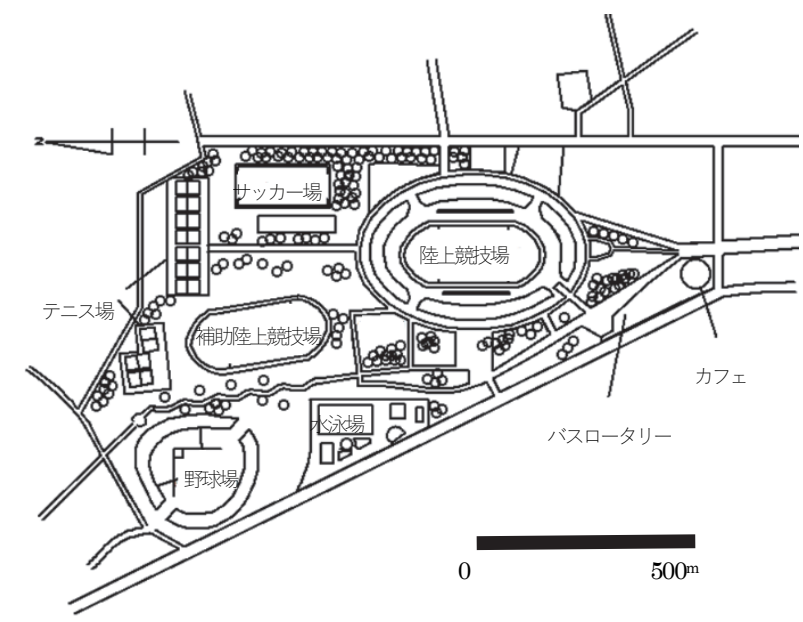

図-2 敷島公園 (群馬県管理) の平面図

全国の都市公園における Park-PFI による収益施設の設置実態 と立地条件を明らかにした。塩見ら ${ }^{12)}$ は，民間事業者に対するア ンケート調查により, 都市公園のビジネス利用に関する意識構造 を明らかにした。以上のように, Park-PFI に関して収益施設の 設置状況，制度の利用実態，事業者の意識の研究がみられる。ま た，指定管理においては，公園管理の履行の確認のみならず，「サ 一ビスの質の確保・向上」の観点から項目を設定し，検証してい くことが望ましいとされ，公園管理に関するモニタリングの手法 や第三者も含む評価の方向性が示されている 1)。このため，都市 公園の魅力づくりにはサービス向上の観点から都市公園の設置目 的に沿ったサービスを提供できているか娝か, 利用者の意見をも とにサービスの向上の指標となるベンチマークが必要ともいえる。

既存の Park-PFI に関する研究では，制度面を考察したものや 収益施設の設置状態や立地特性に着目したものがあるものの，利 用意向との関係といった市場把握に言及した研究があまりない。 民間事業者による公園の利用活性化の効果を検証したものとして は, 嶺岸ら 13)による富山市の富岩運河環水公園のカフェを事例と して, 都市公園のさらなる利用活性化にいかに影響を与えたかと いう調查研究がある。また, 地方における都市公園ビジネスの推 進に官民連携に関わる職員や民間事業者の学習する場が重要との 指摘もある 12 。ここのような都市公園ビジネスの学習機会としても, 地方の都市公園に設置された収益施設（カフェ）の整備事例につ いて情報やデータを収集することは, 都市公園の魅力づくりを進
めるうえでも有効と考える。

本研究は, 地方における都市公園の Park-PFI による収益施設 としてカフェを設置する際における利用意向と個人属性, 利用回 数, 公園に関する印象や管理の評価との関連性を明らかにするこ とを目的とする。これにより, 官民連携の都市公園の魅力づくり の 1 つとして Park-PFI の収益施設の設置に抱くイメージ特性を 把握するものである。一般的な公園利用に関する研究では, 公園 利用者を対象としているものがほとんどであるが，本研究ではカ フェの設置に伴う公園の利用意向を捉え，非利用者を含み市場の 把握を試みる点に独自性がある。なお，本研究における収益施設 とは, 都市公園法第 5 条の 2 第 1 項に規定する「公募対象公園施 設」であり，飲食店，売店等であり，都市公園の利用者の利便の 向上を図るための施設とする。

\section{2. 研究対象及び方法}

\section{(1) 研究対象}

群馬県前橋市の都市公園は, 425 箇所, 総面積 $395.78 \mathrm{ha}$, 人口 1 人あたりの公園面積換算で $11.8 \mathrm{~m}^{2}$ である ${ }^{14)}$ 。前橋市には，市 街化区域内に都市基幹公園として前橋公園（総合公園）と敷島公 園（運動公園）の2 箇所があるが，本研究では，市民アンケート 15)において最も知名度がある敷島公園を研究対象とした (図一1)。

敷島公園は, 1922 年に小出河原と称される河川敷地の周辺部を, 前橋市議会において郊外公園として創設された歴史の深い都市公 園である。前橋市の中心市街地から北西約 $3 \mathrm{~km}$ に位置し，西側 が利根川に接した敷島風致地区に指定され，上毛三山の眺望に優 れる都市基幹公園（種別：運動公園，約 37.6ha）である。北側の 約 19.8ha は, 約 2,700 本の松林, ばら園, ボート池, こども広 場が立地し, 前橋市が公園施設を管理している。南側の約 $17.8 \mathrm{ha}$ は, 400m トラックの陸上競技場をはじめ, 野球場等の本格的な 運動施設が整備されており，群馬県が公園施設を管理している 16) 本研究は群馬県が管理している敷島公園の南側（図一2）を研 究対象とした (以降, 「敷島公園」は公園南側を指寸)。現在, 敷 島公園は, 指定管理者制度により, 敷島パークマネジメント JV

（代表企業 : 株式会社オリエンタル群馬）が管理運営を行ってお り，2019 年度における年間利用者数は 661,231 人であった ${ }^{17)}$

群馬県では, 2018 年 10 月に大学教授, 中小企業診断士, 弁護 士などを加えた 7 名の選考委員会を設置し, 委員会の意見を踏ま えて, Park-PFI を活用した飲食店事業者の提案（約 20 年間）を 募った。この結果, 2019 年 3 月に, 応募者より提案された収益 施設のカフェ (スターバックス) が選定され，2020 年 3 月 25 日 に公園南側の駐車場内の位置で開業している。

\section{(2) 研究方法}

本研究は，以下の方法により研究を進めた。

はじめに，敷島公園の利用状況，スターバックスが開店してか らのこと，敷島公園の印象や管理を把握することを目的に，イン ターネットによる調査を実施した (3 章)。次にインターネットに よる調査から得られたデータを用いて，カフェが開店してからの 利用意向の影響について数量化理論第類を用いて要因分析を行 った。また，カフェ設置前のイメージを把握するために，調査か ら得た自由意見についてテキストマイニングを用いて分析するこ とにより, カフェ設置に伴う利用イメージの特性を把握した(4 章)。 最後に, 都市公園の魅力づくりの観点から, 本研究による結果を まとめるとともに今後の課題を考察した(5 章)。

\section{3. 収益施設の利用意向}

\section{(1) 調査方法}

敷島公園の利用状況，スターバックスが開店してからのこと， 敷島公園の印象や管理を把握するために調査を行った。 
表ー1 アンケート調査の概要

\begin{tabular}{|c|c|}
\hline 調査期間 & 2020年1月 20日〜26日（回答を得た期間） \\
\hline 調查方法 & インターネット調査 \\
\hline 調査対象 & \begin{tabular}{|l} 
・調査会社のモニターのうち, 前橋市に居住する15歳以上の人 \\
性別・年齢改造別に均等に抽出 (層化抽出法) \\
\end{tabular} \\
\hline 調 & 1）回答者の個人属性 \\
\hline 查 & (1)性別, (2)住宅（一戸建て, 集合住宅) \\
\hline 内 & (3)年代, (4)敷島公園から居住地までの距離 \\
\hline 容 & 2）敷島公園の利用状況 \\
\hline & (1)敷島公園の利用回数 \\
\hline & (2)敷島公園の利用目的 \\
\hline & (3)交通手段 \\
\hline & 3） スターバックスが開店してからのこと \\
\hline & (1)開店したら利用しますか? \\
\hline & (2)どんな機会に利用しますか? \\
\hline & (3)利用のしかたは? \\
\hline & (4)カフェが開店すると利用回数は変化するか? \\
\hline & (5)カフェができることによるメリットは? \\
\hline & (6)カフェができることによる不安は? \\
\hline & 4）敷島公園の印象や管理 \\
\hline & (1)敷島公園の印象（10項目＋全体） \\
\hline & (2)敷島公園の管理（10項目＋全体） \\
\hline & 5）敷島公園やカフェ等に関する自由記述 \\
\hline 回収数 & 200票（有効回収） \\
\hline
\end{tabular}

\section{表-2 回答者の個人属性}

\begin{tabular}{|c|c|c|c|}
\hline \multirow{2}{*}{ 性別 } & 男性 & 100 & $50.0 \%$ \\
\hline & 女性 & 100 & $50.0 \%$ \\
\hline \multirow{2}{*}{ 住宅 } & 一戸建 & 132 & $66.0 \%$ \\
\hline & 集合住宅 & 68 & $34.0 \%$ \\
\hline \multirow{5}{*}{ 年代 } & 20 代以下 & 36 & $18.0 \%$ \\
\hline & 30 代 & 43 & $21.5 \%$ \\
\hline & 40代 & 41 & $20.5 \%$ \\
\hline & 50 代 & 40 & $20.0 \%$ \\
\hline & 60代以上 & 40 & $20.0 \%$ \\
\hline \multirow{5}{*}{$\begin{array}{l}\text { 敷島公園から } \\
\text { 居住地までの } \\
\text { 距離 }\end{array}$} & 半径 $1 \mathrm{~km}$ 圈内 & 34 & $17.0 \%$ \\
\hline & 半径 $2 \mathrm{~km}$ 圏内 & 24 & $12.0 \%$ \\
\hline & 半径 $3 \mathrm{~km}$ 圈内 & 28 & $14.0 \%$ \\
\hline & 半径 $4 \mathrm{~km}$ 圈内 & 20 & $10.0 \%$ \\
\hline & 半径 $4 \mathrm{~km}$ 圈外 & 94 & $10.0 \%$ \\
\hline
\end{tabular}

カフェの設置前における利用意向の市場調査のため，敷島公園 やカフェの利用意向がない属性の特性も把握することとした。方 法はインターネット調査とし, 調査会社の HP 上で回答を行って もらった。調査会社のモニターで前橋市民は 15 歳以上が約 5000 人であったが，既往研究の無作為抽出によるアンケート調査 $\left.{ }^{18}\right)$ の結果などを踏まえると，若年層（特に 20 歳代）の回収数が小 さくなることが想定された。このため調査対象者は，敷島公園が 都市基幹公園であること，今回カフェを対象とすることから比較 的身近な利用が考えられ，かつ若年層のサンプルも得たいことか ら, 性別・年代階層別にサンプルを確保できるよう, 前橋市に居 住する市民（15 歳以上）とし，10 階層各 20 サンプルの確保を目 標とした層化抽出法を採用した。なお，敷島公園は都市基幹公園 であることから，前橋市民全体が母集団と考える。このため母集 団に対して，モニター層，インターネット利用の有無，性別・年 齢階層別に偏る可能性も考えられるが，カフェの利用が見込まれ る若年層の情報を把握するため, 採用した。

調査は 2020 年 1 月 20 日より開始し，26 日の回答を以って必 要サンプルの抽出が完了したことから 27 日に終了した。はじめ に，回答者の「個人属性」と「敷島公園の利用状況」の設問に答 えてもらった。次に, 群馬県のホームページのイメージパース図 (図一-3) を見てもらった上で「スターバックスが開店してから のこと」の設問に答えてもらった。最後に，「敷島公園の印象や

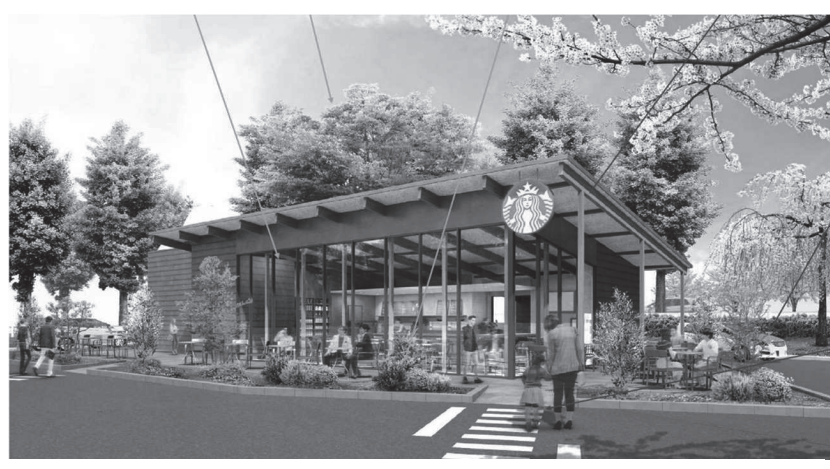

図ー3 群馬県ホームページのイメージパース ${ }^{19)}$

\section{表－3＼cjkstart敷島公園の利用状況}

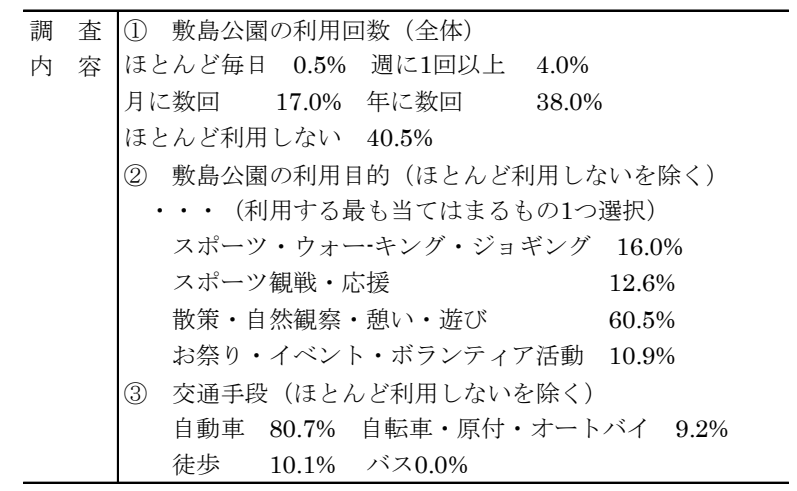

表－4 スターバックスが開店してからのこと

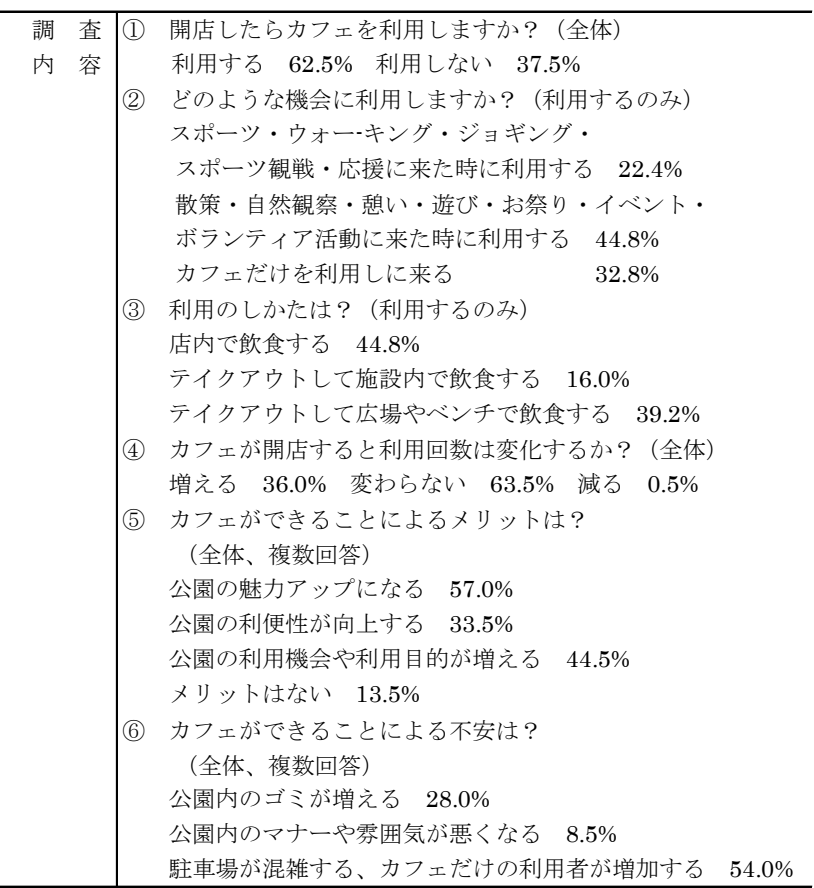

管理」「敷島公園やカフェ等に関する自由記述」の設問に答えても らった (表一1)。

\section{(2) 調査結果}

表一2 は、回答者の個人属性を示したものである。「性別」や「年 代」は，概ね均等分に回答を得た。「住宅」においては「一戸建」 の居住者が $66.0 \%$ 占めた。「敷島公園から居住地までの距離」 は「半径 $4 \mathrm{~km}$ 圈外」の居住者が $47.0 \%$ 占めた。表一 3 は, 敷島 公園の利用状況について,「ほとんど毎日」から「ほとんど利用し ないまでの 5 肢 1 択で答えてもらった結果である。 


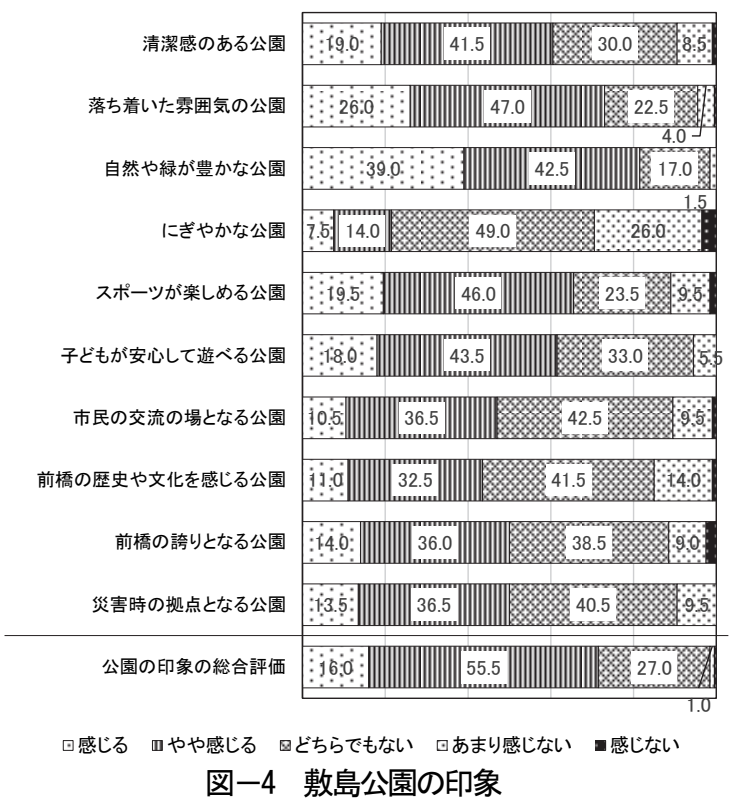

\begin{tabular}{|c|c|}
\hline 公園施設での事故を防止すべき & 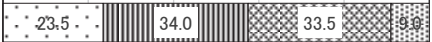 \\
\hline 樹木也花の手入れにカを入れるべき & 16.0 .0 \\
\hline 除草や落葉の除去にカを入れるベき & 13.0. \\
\hline 施設の清掃に一カ入れるぐき & $16.55^{\circ} \cdot\|\|$ \\
\hline 不賽者などの防犯にカを入れるベき & 23,55 \\
\hline 利用者のマナ一向上にカを入れるぐき & $\cdot 8.5 \cdot{ }^{5} \cdot\|\|\|\|$ \\
\hline 駐車場の管理に力を入れるぐき & $99.5 \%$ \\
\hline 公園の利用者の增加をすべき & 73.5 \\
\hline 市民団体の活動支援にこカを入れるベき & $8.5 \mathrm{~m}\|\|_{24.0}^{24.0}$ \\
\hline 災害時の備えに配慮すべき(避難所等) & - $13: 0.10$ \\
\hline 公園管理の総合評価 & 更 41.5 \\
\hline
\end{tabular}

図-5 敷島公園の管理

表より，全体の選択肢のうち「ほとんど利用しない (40.5\%)」 が最も大きな值を占めた。利用していると選択した中では「年に

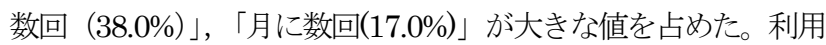
していると選択した回答者を対象に「敷島公園の利用目的」を 4 肢 1 択で答えてもらった結果，「散策・自然観察，憩い，遊び (60.5\%)」が最も大きな值を占め, 「スポーツ・ウォーキング・ジ ヨギング $(16.0 \%) 」$, 「スポーツ観戦・応援(12.6\%)」,「お祭り・イ

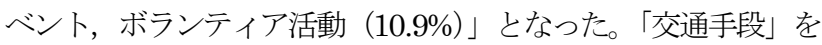
4 肢 1 択で答えてもらった結果, 「自動車(80.7\%)」が最も高く,

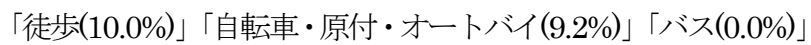
であつた。

「今年の春，スターバックスが開店します。前橋市では 4 店舗 目になります。として, 群馬県ホームページのイメージパース図 (図一3) を見てもらった上で，「スターバックスが開店してから のこと」の設問に答えてもらった。はじめに, 「開店したらカフェ を利用しますか?」の設問に 2 肢 1 択で答えてもらつた結果, 「利 用する」が $62.5 \%$ ，「利用しない」が $37.5 \%$ であった。「利用する」 と答えた回答者を対象に,「どのような機会に利用しますか?」を 3 肢 1 択で聞いたところ，「散策・自然観察・嚊い・遊び・お祭り・
イベント・ボランティア活動に来た時に利用する (44.8\%)」が最 も多くを占めた。また，「利用のしかたは?」について 3 肢 1 択

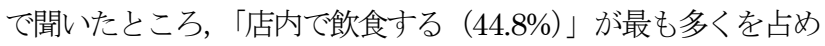
た。次に, アンケート調査の回答者全体を対象に,「カフェが開店 すると（敷島公園の）利用回数は変化するか?」について 2 肢択 1 で聞いた結果，「増える $(36.0 \%) 」$, 「変わらない $(63.5 \%) 」 「$ 減

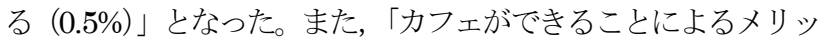
トは?」について複数選択で聞いた結果, 「公園の魅力アップにな る (57.0\%)」が最も大きく, 次いで「公園の利用機会や利用目 的が増える $(44.5 \%) 」 「$ 公園の利便性が向上寸る (33.5\%)」とな った。さらに，「カフェができることによる不安は?」について複 数選択で聞いた結果, 「駐車場が混雑する、カフェだけの利用者が 増加する $(54.0 \%) 」 か ゙$ 最も大きく, 次いで, 「公園内のゴミが増 える (28.0\%)」であった。総じて, カフェが開店することによ って, 全ての回答者のうち 6 割以上がカフェを「利用する」とし ており, また回答者の 3 割以上が「(敷島公園の) 利用回数が増 加する」であろうと答えた。

「敷島公園の印象」について，「清潔感のある公園」のほか 9 項目について,「感じる」から「感じない」まで 5 段階で伺った 結果を図-4 に示す。図より，敷島公園の印象として「感じる」 や「やや感じる」という回答が多数を占めた項目は,「自然や緑が 豊かな公園 (81.5\%)」,「落ち着いた雰囲気の公園（73.0\%)」で あった。これは, 公園全体の既存の緑を高く評価していることや, 前橋市管理の北側にある松林の印象を評価したものと考えられた。 また，これらに続き多かったのは，「スポーツが楽しめる公園 (65.5\%)」「子どもが安心して遊べる公園 (61.5\%)」「清潔感の

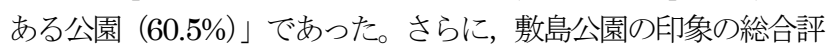

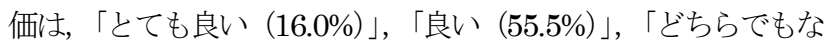

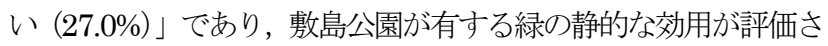
れながらも，スポーツなど動的な効用も十分に評価されている都 市公園であることが見られた。

「敷島公園の管理」について,「公園施設での事故を防止すべき」 ほか 9 項目について,「感じる」から「感じないままで 5 段階で 聞いた結果を図一 5 に示寸。図より，敷島公園の管理に関する内 容の中で「感じる」や「やや感じる」という回答が多数を占めた 項目は，「不審者などの防犯に力を入れるべき $(65.0 \%) 」 「$ 施設の 清掃に力を入れるべき $(61.0 \%) 」 「$ 公園施設での事故を防止す心゙ き $(57.5 \%) 」 て ゙ あ り ，$ 防犯や清掃，事故といった公園施設の利用 安全に関するものへの関心が高いことがわかった。なお，敷島公 園の管理の総合評価は「とても良い (10.0\%)」「良い (46.5\%)」 であり，両内容を加えると全体の評価の 5 割以上が管理を良いと 答えた。一方，「どちらでもないが $41.5 \%$ であり，「悪い」と「と ても悪いと答えたのは $2.0 \%$ と少数であった。

\section{3. 利用意向と影響に関する分析}

\section{（1）数量化理論第 II 類を用いた利用意向の要因分析}

質的な目的変数を質的要因に基づき判別する多变量解析が, 数 量化理論第 II 類である。本研究では, 敷島公園にカフェを設置す る際の利用意向と個人属性, 利用回数と敷島公園の印象や管理の 評価などの要因間の関係性について, より具体的に把握するため に数量化理論第 II 類を用いて分析を行った。

目的変数には，「開店したらカフェを利用しますか?」の設問で 得られた「利用する」「利用しない」のデータをダミー変数 (カフ エの利用意向）として用いた。説明変数は，個人属性として「性 別」「年代」「敷島公園から居住地までの距離」, 敷島公園の利用状 況として「敷島公園の利用回数」,敷島公園の印象や管理として「敷 島公園の印象の総合評価」敷島公園の管理の総合評価」を用いた。 なお，カテゴリー区分は，原則として設問の選択肢で扱い，一部 
表-5 数量化理論第 I類の分析結果

\begin{tabular}{c|l|r|r|c}
\hline \multirow{2}{*}{ 説明変数 } & \multicolumn{1}{|c|}{$\begin{array}{c}\text { カテゴリー } \\
(\text { はサンプル数 }\end{array}$} & スコア & レンジ偏相関 \\
係数
\end{tabular}

の説明変数についてサンプル数の関係から統合して最適化した。 表一5 は数量化理論第䅡による分析結果である。目的変数の 相関比は 0.341 とやや低い結果となったが，判別的中率は $78.5 \%$ であり比較的の高い水準の判別精度が得られたため感度分 析に類似する既往研究の事例を踏まえて本モデルを採用した 20)。 表中のレンジの值から，敷島公園の「カフェの利用意向」に最 も影響を与えているものとして，「敷島公園の利用回数(1.654)」 が特に影響を与えており, 次いで「年代(0.788)」が挙げられた。 カテゴリースコアに着目すると, 説明変数である「年代」にお いては，「20 代以下(0.434)」「30 代(0.368)」と若年層のカテゴリ 一スコアが大きい值であり，「50 代(-0.354)」「60 代(-0.243)」が 小さい值となった。この結果からカフェの設置は比較的若年代の カフェ利用意向の増進に影響する傾向を把握することができた。

また，説明変数である「敷島公園の利用回数」においては，「ほ とんど利用しない(-0.903)」よりも「週に 1 回以上(0.695)」「月に 数回(0.750)」と敷島公園の利用回数が高い属性のカテゴリースコ アが大きいことから，利用回数が高いリピーターほどカフェ利用 意向の増進に影響する傾向を把握することができた。さらに，説 明変数である「敷島公園から居住地までの距離」においては,

$\lceil 4 \mathrm{~km}$ 以上(-0.228)」よりも「2km 未満(0.195)」「2〜3km(0.194)」 「3 4km(0.232)」の属性がカフェ利用意向の増進に影響する傾 向を把握することができた。

\section{（2）自由意見を用いたカフェの設置のイメージ分析}

カフェの利用意向のイメージを，恣意なく，より具体的に把握 するため, アンケート調査の自由記述を活用したテキストデータ の分析を行った。今日，テキストデータの解析手法のためのテキ ストマイニングのソフトウェアが多く開発されている。

本研究では単語の抽出頻度および共起関係により緑地評価のテ キスト分析としての既往研究 21）にも用いられ技術情報が公開さ

\section{表一6 KH Coder による抽出ワード（上位）}

\begin{tabular}{|c|c|c|c|}
\hline 順位 & 語 & 語数 & 回答者数 \\
\hline 1 & 敷島公園（公園含む） & 46 & 41 \\
\hline 2 & 思 う & 40 & 35 \\
\hline 3 & カフェ & 34 & 34 \\
\hline 4 & ス夕ーバックス（スタバ含む） & 28 & 28 \\
\hline 4 & 利 用 & 28 & 26 \\
\hline 6 & 駐 車 & 26 & 21 \\
\hline 7 & 行 $<$ & 19 & 10 \\
\hline 8 & 増える & 15 & 15 \\
\hline 9 & 楽しみ & 11 & 11 \\
\hline 10 & 良 い & 11 & 11 \\
\hline 11 & 魅 力 & 10 & 10 \\
\hline
\end{tabular}

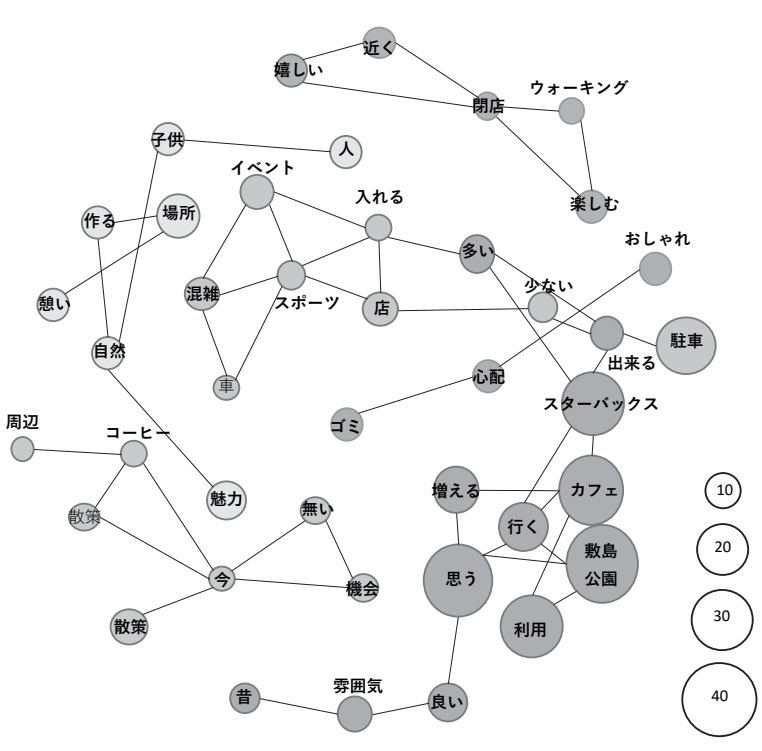

図－6 KH Coder による分析結果

れている KH Coder を使用した。分析対象とした自由意見のサン プルは「特になし」を除いた 150 の回答者から得られた 194 のセ ンテンス，1,309 の語を対象とした。分析に際しては，「公園」を 「敷島公園」，「スタバ」を「スターバックス」へ同語として扱っ た。表一 6 は頻度の高い上位 11 の語を抽出したものである。表中 でも 20 個以上の出現頻度の高い語として,「敷島公園」「思う」「力 フェ」「スターバックス」「利用」駐車」が抽出された。図一6は,

KH Coder による語の共起関係を視覚的に表現するため, 共起ネ ットワーク図を作成したものである。図は，共起ネットワーク図 を視覚的に判読できるように, Jaccard 係数が 0.15 以上を表示し たものである。

抽出頻度の高い語の共起関係のまとまりとしては, 「敷島公園 カフェ・スターバックス - 利用」駐車場一少ない」の関係が見ら れた。「敷島公園 - カフェ・スターバックス」の 2 つの語が含ま れる回答数は 17 であり,「公園とカフェはとてもいい組み合わせ だと思います」といったカフェ設置に肯定的なイメージを得るこ とができた。また，「敷島公園 - カフェ・スターバックス - 利用」 の 3 つの語が含まれる意見としては，「敷島公園に安心して利用 できるカフェができるのは嬉しい」「4月より敷島公園付近で働く ことになっているため, 自分のサードプレイスとしてスターバッ クスを沢山利用したい」といったイメージ（回答数：3）を得る ことができた。一方，「駐車場-少ない」の 2 つの語が含まれる意 見には，「駐車場が少なくイベント時に混雑する。といったカフ エが設置されることによる, 駐車場の混雑を心配するカフェ設置 に否定的なイメージ（回答数：3）も見られた。 


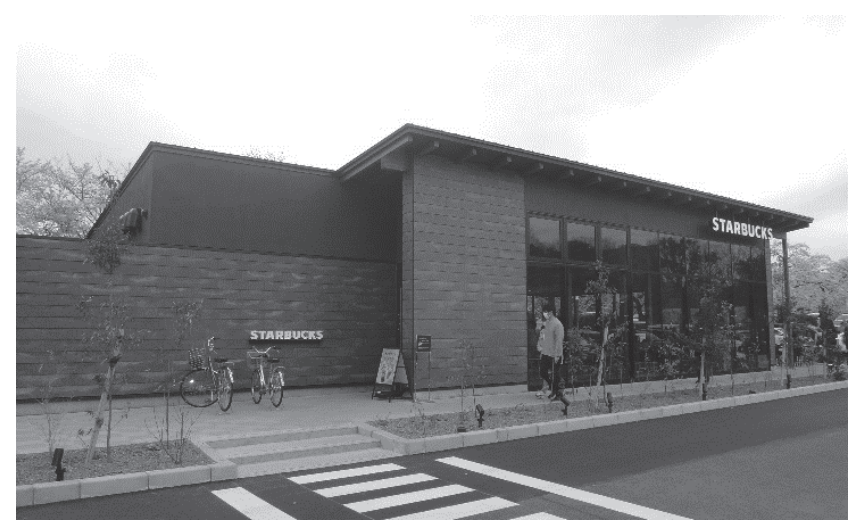

図ー7 完成したカフェ

\section{4. まとめ}

\section{(1) 結果}

本研究は, Park-PFI により収益施設としてカフェ（スターバ ックス）を整備する敷島公園を対象に，オープン前における利用 意向と属性や利用状況，自由意見を用いたイメージ分析に関する 事例研究を行った。分析の結果，以下の内容が明らかになった。

Park-PFI により整備を行う予定の収益施設（カフェ）の利用 意向と属性や利用回数, 公園の印象及ひ管理に関する評価の関係 性を把握した。結果，カフェを利用する意向を示した人は $62.5 \%$ であり, カフェの開業によって公園の利用頻度が増加するという 意向を示した人は $36.0 \%$ あった。また，カフェを利用するか否 かを目的変数に設定し，性別，年代別，敷島公園から居住地まで の距離, 敷島公園の利用回数, 敷島公園の印象や管理の総合評価 を説明変数に設定して数量化理論第川類を適用して分析を行った。 結果, 数量化理論第I類のレンジ值から, 敷島公園のカフェを 利用意向に最も影響を与えているものとして，「年代」や「公園の 利用回数」が特に大きな影響を与えていることが分かった。中で も，敷島公園の収益施設（カフェ）の設置が，「20 代以下」や「30 代」といった比較的若年代や敷島公園から「4km 未満」の居住者 の利用意向に，プラスの影響を及ぼすことが明らかになった。一 方で，敷島公園の印象や管理の評価と利用意向との強い関係性に ついては把握することができなかった。

自由意見のテキスト分析からは，敷島公園・カフェ・利用とい った，つながりから敷島公園の魅力向上にとって肯定的なイメー ジを把握できた。この結果からもカフェができることにより，敷 島公園のイメージアップや利用増進により, 都市公園の魅力づく りが高まるものと期待された。また，数量化理論第類の分析に おいて，公園の印象や管理の評価が利用意向と関係性が得られな かった要因に，カフェが設置されることによる駐車場の混雑の心 配といった課題がイメージに見られることから，事前この課題調 整に取り組むことも有効でないかと考えられた。

\section{(2) 今後の研究課題}

今後の研究課題については, 以下のように整理した。

敷島公園内の収益施設（カフェ）は, 2020 年 3 月 25 日に開業 した (図一7)。今回，地方における都市公園として敷島公園に設 置された収益施設であるカフェの 1 事例としてスターバックスの 出店を扱った。しかしながら，スターバックスの出店は，知名度 やビジネスモデル（サードプレイスなど）からも通常のカフェと 混同できない特異なケースとして捉える注意が必要であり，今回 得られた結果を通常のカフェの出店に適用できるかは再度検証を 試みる必要があると考える。また，今回得られた検証結果につい て，実際の利用動向のモニタリングを行うことも課題となってい る。しかしながら，3 月 25 日に開業した後の 2020 年 4 月には,
新型コロナウィルス感染症対策のため, 政府から外出自肃要請が 出された。そのため, 定常的な利用動向の情報を取得することが 困難な状況が継続している。このため今後も，情勢を判断しなが ら利用動向調查を実施していくことにより，当初の利用意向とイ メージ分析がカフェの利用を通じて，どのように，その後の印象 や管理に影響を及ぼしたかを明らかにすることが課題である。

\section{補注及び引用文献}

1)官民連携による都市公園魅力向上ガイドライン : 国土交通省ホームペー ジ<https://www.mlit.go.jp/common/001136186.pdf>, 2014.4.1 更新, 2020.9.12 参照

2）都市公園の質の向上に向けた Park-PFI 活用ガイドライン: 国土交通 省ホームページ<https://www.mlit.go.jp/common/001197545.pdf， 2017.8.10 更新，2020.9.12 参照

3）梛野良明(2017) : 公園緑地に関する官民連携制度 : ランドスケープ研究 $81(2), 527-532$

4）塚田伸也・湯沢昭(2004)：大公園における利用者の評価構造に 関する検討-前橋市の総合公園を事例として : 都市計画論文集 39(3), 193-198

5）塚田伸也・湯沢昭(2008）: 都市公園における指定管理者の選考基淮の 現状と評価構造の分析：日本建築学会計画系論文集.73(631), 1923-1928

6）前田博(2009) : 指定管理者制度導入前後の公園利用者満足度調查比較に よる制度導入の影響に関する考察 : ランドスケープ研究.72(5), 591-594

7）竹田和真・武田重昭・加我宏之・増田昇(2015) : 都道府県営都市公園の 指定管理業務に対する年度評価の評価項目等に関する研究 : 都市計画論 文集.50(3)，1106-1113

8）上原恵・浦出俊和・上甫木昭春(2018) : 大規模都市公園の指定管理者制 度運用における業務評価と上限額の設定に関する研究 : ランドスケープ 研究 $81(5), 501-506$

9）印部里菜子・坂井文・越澤明(2010）: PFI 手法を導入した都市公園整備 に関する研究 : 都市計画論文集 45(3)，799-804

10）宋俊煥・山崎嵩拓・泉山畦威(2018)：「設置管理許可制度」を用いたパ ークマネジメントにおける設置管理事業者の関与実態に関する研究 : 都 市計画論文集 53(3)，1289-1296

11）山崎亳拓・宋俊煥・泉山塁威・横張真(2019) : 全国の都市公園におけ る公募を通じた収益施設の設置実態と立地条件の関係 : 都市計画論文集 54(2), 136-143

12）塩見一三男 ・ 中川秀穂 - 小松亜紀子 ・金岡省吾・市村恒士武(2019): 民間事業者の意識からみた「都市公園ビジネス」展開の可能性 : ランド スケープ研究 $82(5), 527-532$

13）嶺岸さゆり・平松玲治(2016) : 民間事業者によるカフェ導入までの経 緯と公園の利活用について-富岩運河環水公園を事例に- : 公園管理研究 9 , 54-63

14）前橋の都市計画資料編（令和 2 年度版）：前橋市ホームページ $<$ https://www.city.maebashi.gunma.jp/sangyo_business/1/2/8/9980.ht $\mathrm{ml}>, 2020.6 .2$ 更新, 2020.7.14 参照

15）前橋市緑の基本計画(1998) : 前橋市, 6-7

16）群馬県立敷島公園ホームページ:指定管理者 敷島パークマネジメント $J V<h t t p s: / / s h i k i s h i m a-p a r k . o r g />， 2020.6 .10$ 参照

17）指定管理者による公の施設の管理運営状況（令和年度）: 群馬県ホー ムページ<https://www.pref.gunma.jp/07/a07g_00058.html>, 2020.10.7 更新, 2020.10 .12 参照

18）塚田伸也・片桐麻衣・森田哲夫・湯沢昭(2018) : 敷島公園の総合的価 值が周辺の生活質に与える影響に関する考察:ランドスケープ研究 81(5), 495-501

19）県立敷島公園における飲食占事業者予定者が決定しました！：群馬県 ホームページ<https://www.pref.gunma.jp/06/h58g_00082.html> , 2020.6.10参照

20）佐々木雄希・藤井智史・岸本達也(2013)：局所的環境特性から見た不 審者事案発生及び未発生に影響する環境要因一埼玉県草加市を対象とし て一: 地域安全学会論文集 $20,21-28$

21）高瀬唯(2018) : テキストマイニングからみた緑地保全の実習プログラ ムにおける若者の経験に関する研究 : ランドスケープ研究.81(5), 637-642 